Article

\title{
Real vs. Virtual City: Planning Issues in a Discontinuous Urban Area in Budapest's Inner City
}

\author{
Melinda Benkő ${ }^{1, *}$, Bence Bene ${ }^{1}$, Ádám Pirity ${ }^{1}$, Árpád Szabó ${ }^{1}$ and Tamás Egedy ${ }^{2,3}$ \\ ${ }^{1}$ Department of Urban Planning and Design, Faculty of Architecture, Budapest University of Technology and Economics, \\ Hungary; E-Mails: benko@urb.bme.hu (M.B.), bene.bence@edu.bme.hu (B.B.), adampirity@edu.bme.hu (Á.P.), \\ szabo.arpad@urb.bme.hu (Á.S.) \\ 2 Budapest Business School, Faculty of Commerce, Hospitality and Tourism, University of Applied Sciences, Hungary; \\ E-Mail: egedy.tamas@uni-bge.hu \\ ${ }^{3}$ Geographical Institute of the Research Centre for Astronomy and Earth Sciences, Hungary \\ * Corresponding author
}

Submitted: 29 April 2021 | Accepted: 20 June 2021 | Published: 17 November 2021

\begin{abstract}
The 21st century has brought fundamental changes in the development of cities, with the spread of ICT and the rise of digitalization. The new technologies are increasingly making their mark on urban planning and policy as well. The question of how contemporary urban planning is adapting to new challenges is particularly relevant as neighborhoods built in previous centuries and decades by traditional planning methods are now increasingly confronted with new public and environmental demands. Despite the bad reputation of Budapest's 8th district, Józsefváros, based on the socio-economic and urban problems it has continuously faced in the past, the neighborhood has become one of the most dynamically developing urban areas in the last decade. From a planning point of view, an exciting area of the district is Szigony Street and its wider surroundings due to the strongly fragmented, heterogeneous urban fabric. Nevertheless, the only high-rise mass housing estate built in Budapest's historic inner city in the 1960s and 1970s is located there. Our research used a complex methodology (document, content and database analysis, fieldwork, surveys with professionals, and interviews) to explore the planning history of the area's development. Ultimately, the aim was to identify the most important outcomes and consequences of traditional and contemporary planning and design and whether modern digital planning can make a meaningful contribution to the development of the neighborhood. Our results show that urban planning and development in Budapest are still essentially based on traditional top-down approaches. Digitalization has a role to play primarily in visualization and contextualization but digitalizing of planning alone will not solve problems and past planning mistakes that affect the urban fabric of a neighborhood.
\end{abstract}

\section{Keywords}

Budapest; digitalization; ICT; Józsefváros; mass housing; real city; Szigony Street; urban development; urban planning; virtual city

\section{Issue}

This article is part of the issue "Towards Digital Urban Regeneration: Embedding Digital Technologies Into Urban Renewal Processes and Development" edited by Dalit Shach-Pinsly (Technion-Israel Institute of Technology, Israel).

(C) 2021 by the authors; licensee Cogitatio (Lisbon, Portugal). This article is licensed under a Creative Commons Attribution 4.0 International License (CC BY).

\section{Introduction}

Over the last decade, we have witnessed the rapidly growing role of ICT and digitalization in urban development and the appearance of new concepts, like digital city (Ishida \& Isbister, 2000), intelligent city (Komninos, 2002), and smart city (Hollands, 2008) that nowadays dominate professional debates. The concepts of digital city and intelligent city are mainly concentrated on the digital representations and manifestations of cities (Nam 
\& Pardo, 2011), whereas the smart city concept is a comprehensive, strategic approach in which infocommunication technology is used as a tool for urban management (Washburn et al., 2009). These concepts clearly point to the growing intertwining of physical (real) and digital (virtual) spaces. In this article we deal with the relationship between the real and the virtual city from an urban planning perspective. The real city is obviously made up of physical and both built and natural components. Developers and designers try to construct this world precisely, but representations also play their role, because a city is much more than its stable materiality: It is a permanently changing assemblage (McFarlane, 2011) that is experienced by users differently. This duality of the real and the representational is a basic phenomenon that is described as actuality and potentiality, objectivity, and subjectivity, hyperreality, or real and virtual (Champion, 2019). Nevertheless, "almost real" is the original definition of the word virtual that became a commonly used word in the digital era. However, the new meaning of virtual is referring to anything "created by computer technology and appearing to exist but not existing in the physical world" (Virtual, n.d.).

Computerization and digitalization of cities accelerated significantly in the 2000s and these processes created a new urban knowledge infrastructure. Digital infrastructures and platforms have allowed for the emergence of new work structures that redefine sectoral boundaries, and shape local and regional economies, as well as urban planning issues (Malone, 2018). Digitalization has also compelled governments and public institutions to rethink laws, regulations, and policies related to urban development (Zysman \& Kenney, 2018). It is no coincidence that new questions about how ICT and digitalization will affect urban development, how they will impact the transformation of neighborhoods, and how they will change the way the local economy works have become the focus of urban development debates. Digitalization is often perceived as a functional concept, an unproblematic key to future development. The increasing digitalization of the world lead to a situation where digital technologies and digital constructs are profoundly embedded in our daily lives and work (Dufva \& Dufva, 2019).

From an urbanistic and planning point of view, it may be particularly interesting to examine the relationship between traditional and new methods of urban development, and whether urbanism and contemporary architecture based on modern techniques can carry on, transform or, if necessary, correct the achievements, consequences, and possible mistakes of previous decades and centuries. To explore this process, we have chosen a specific and highly complex area of Budapest's inner city, which has been a testing ground for urban development efforts and experiments for many decades. The research focuses on the 750-meter long Szigony Street and its surrounding urban blocks because it is a special site in terms of planning for two main rea- sons: First, this is the only part of Budapest's homogenous historic inner city where a modern regeneration project with demolition and replacement by a prefabricated housing estate was realized in the 1960s and 1970s; second, this is the only part of the inner city where a contemporary large-scale renewal transformed the inherited urban fabric using the modern method of demolition and replacement. Evidently, in the past, planners and architects worked with traditional methods and tools, but their planning process has recently been facilitated by digital techniques.

The article addresses questions on the main features and achievements of the traditional planning period in the development of the case study area. We investigate how 21st century digitalization has affected the transformation of the physical environment of the area and what changes digitalization has brought to the planning process and work. The results presented in the article are based on secondary and primary sources. Secondary methods include the review of international and national literature, analyses of different statistical databases, and content analysis. The content analysis was mainly based on the study of development documents, policies and strategies on the city, the district, and the case study area, as well as on the analysis of digital photos, maps, and design documents. The main aim of the secondary research was to explore and understand the long-term processes of urban development. In the primary research both quantitative and qualitative methods were used. In 2020 and 2021, we carried out several field trips, including mapping and photo documentation in order to get an overview of the actual situation and to compare the reality (e.g., building stock and state of the physical environment) with the virtual information (e.g., open access data and GIS maps). The qualitative research involved written and online in-depth interviews with seven professional actors (planners and architects), who worked in the area in the last two decades and played a key role in its development.

\section{ICT, Digitalization, and the City}

\subsection{The Role of ICT in Urban Development}

The development of ICT and especially the emerging knowledge-intensive industries opened a new chapter in urban development. In the post-industrial age, the transformation of urban networks, urban regions, and cities was fundamentally influenced by the rapid spread of ICT, which has not only changed the physical environment of cities but has also affected changes in the social and economic context (Portugali et al., 2012).

Sassen (2001) pointed out that ICT transforms the spatial organization of society, as well as economy and consumption patterns. In recent years, however, several studies have highlighted the contradictory effects of ICT on urban development. It is still unclear how ICT affects the transformation of urban space (Audirac, 
2005), as telecommunication technologies are changing very rapidly (Graham \& Marvin, 1999) and we might not even be able to recognize the spatial effects of ICT (Firmino et al., 2006). At the same time, it is a fact that ICT can contribute to improving services and quality of life and achieving sustainability goals (Bifulco et al., 2016). It is no coincidence that the use of ICT in the development of innovative, sustainable, and smart cities has led to the spread of new urban planning models (Yeh, 2017).

Tranos (2013) draws attention to the fact that the internet and telecommunications continue to be a primarily urban phenomenon. Material and electronic spaces are becoming more and more intertwined and are working together. Economic performance continues to depend on stationary, material spaces, which in turn are increasingly permeated by the internet and the cyber network. However, the correlation between the use of ICT and the city is not negative, since virtual and physical spaces do not replace but complement each other (Tranos \& Nijkamp, 2013).

\subsection{Digitalization of Urban Development}

Perry (2008) and Yigitcanlar (2011) brought a new perspective to the field by expanding the concept of knowledge-based urban development. The concept considers socio-economic development, sustainability, and governance, emphasizing the role of knowledgeintensive industries, ICT, and digitalization in urban development and planning. It aims to create a city that provides a perfect environment for business, people, spaces/places, and administration, and puts a strong emphasis on the balanced development of these systems; thus, it is based on a holistic approach (Carrillo et al., 2014).

Knowledge-intensive industries and high-tech technologies are playing an increasingly important role in urban development and respond to the challenges of the urban environment today. Therefore, complex urban development strategies increasingly include measures to facilitate the establishment and participation of hightech enterprises in urban development, as well as to formulate economic and sustainability goals (Katz \& Krueger, 2016; Pancholi et al., 2015). Thanks to these processes, the use of modern technologies and various big data databases in planning and development is also playing an increasingly important role in the development of cities.

Hancke et al. (2013) and Townsend (2013) pointed out that connecting, integrating, and analyzing the information and big datasets produced by pervasive and ubiquitous computing and digitally instrumented devices built into the urban fabric can be used to model and predict urban processes and to simulate future urban developments (Batty et al., 2012; Schaffers et al., 2011). Kitchin (2014) emphasized that many city governments now use real-time analytics to manage aspects of how a city functions and is regulated. More recently, there have been attempts to draw all these kinds of surveillance and analytics into a single hub, supplemented by broader public and open data analytics (e.g., Rio de Janeiro, Dublin, Santander, or London). These efforts allow cities to become a real-time laboratory where the use of big data sets provides the basis for a more efficient, sustainable, competitive, open, and transparent city. Big data is certainly enriching our experiences of how cities function, and it is offering many new opportunities for planning and more informed decision-making (Batty, 2013).

\subsection{Digitization and Digitalization in Urban Planning}

In the context of urban planning, international results suggest that digital technologies and digitization in general promote openness, affordances, and generativity (Nambisan et al., 2019). Openness of urban planning and technological architecture can support joint decision making and governance (Wareham et al., 2014). The digital dimension may thus lead urban planning to many different directions. According to Douay (2018), the following trends can be identified in urban planning based on the use of ICT: (1) algorithmic planning implying the return of experts and technocrats, (2) uberized planning as a reflection of urbanism and urban capitalism, (3) wiki planning based on urbanism looking for crowdsourced planning, and (4) open-source planning relying on the renewal of the practices of the democratic institutions of urban governance. Anttiroiko (2021) draws attention to the role of platformization in contemporary planning. His results suggest that digital co-production platforms represent a paradigmatic case of urban platform, where representatives of local public authoritiespoliticians, public managers, and urban planners-and citizens meet and collaborate in pursuit of improving the use of each other's resources and achieving better outcomes. Contemporary planning requires new skills such as data analytics, data optimization, and data visualization, and new professions appeared that are currently dominated by experts who apply technical skills. Power has slowly shifted from traditional public actors and governments towards a variety of companies who provide much of the infrastructure for the digitally instrumented city (McQuire, 2021).

\section{Twists and Turns in the Development and Planning of the "Real" City}

In Budapest, three periods have significantly reshaped the development of the "real" city. The Hungarian capital city was founded in 1873 through the unification of three historic towns: Buda, Pest, and Óbuda. Thanks to the unification and the subsequent dynamic population growth, Budapest became one of the biggest cities in Europe. This golden age of the city lasted until the First World War. In this period, the architecturally homogeneous central urban fabric of the city was built up and composed of approximately 400 urban enclosed blocks of beaux-arts 
and art nouveau buildings. The General Development Plan in 1994 designated this part of the city as the inner zone, where most of the housing stock dates back to the so-called founder period (Gründerzeit) in the late 19th and early 20th centuries (see Figure 1).

After the Second World War, between 1949 and 1989 , Hungary became a state-socialist country. The new political ideology brought with it the spread of industrial and mass housing developments (Molnár, 2013). The urban fabric gradually changed after 1950, when Greater Budapest was created by annexing 23 formerly independent settlements of the suburban zone to the core city. The inherited historic city center and the inner city became relatively small and neglected parts of the city, at the same time industrial areas developed just around the center and high-rise housing estates were erected in the outskirts. In the urban fringe, the so-called reconstruction often resulted in the demolition and rebuilding of former city centers based on the principles of modern architecture (Egedy et al., 2017; Losonczy et al., 2020). This period could be characterized by a profound functional and spatial division.

The political and economic change in 1990 opened the door to market-based development and urban regeneration. Since the late 1990s, neoliberal urban development has resulted in the emergence of new residential and commercial buildings in the inner city. Global capital and local private investors discovered the inner city and well-located areas were renewed building by building. EU funds later facilitated this process by several complex urban renewal programs introduced after 2007. In the third period, the urban fabric started to become more and more fragmented.

The case study area is located in one of the poorest and most stigmatized parts of the historic inner city. Demolition and replacement were and still are used to provoke large scale urban changes in the neighborhood. During the socialist period, the only housing estate in the historic core of the city was built here, and the only megaproject, the Corvin Promenade (originally called

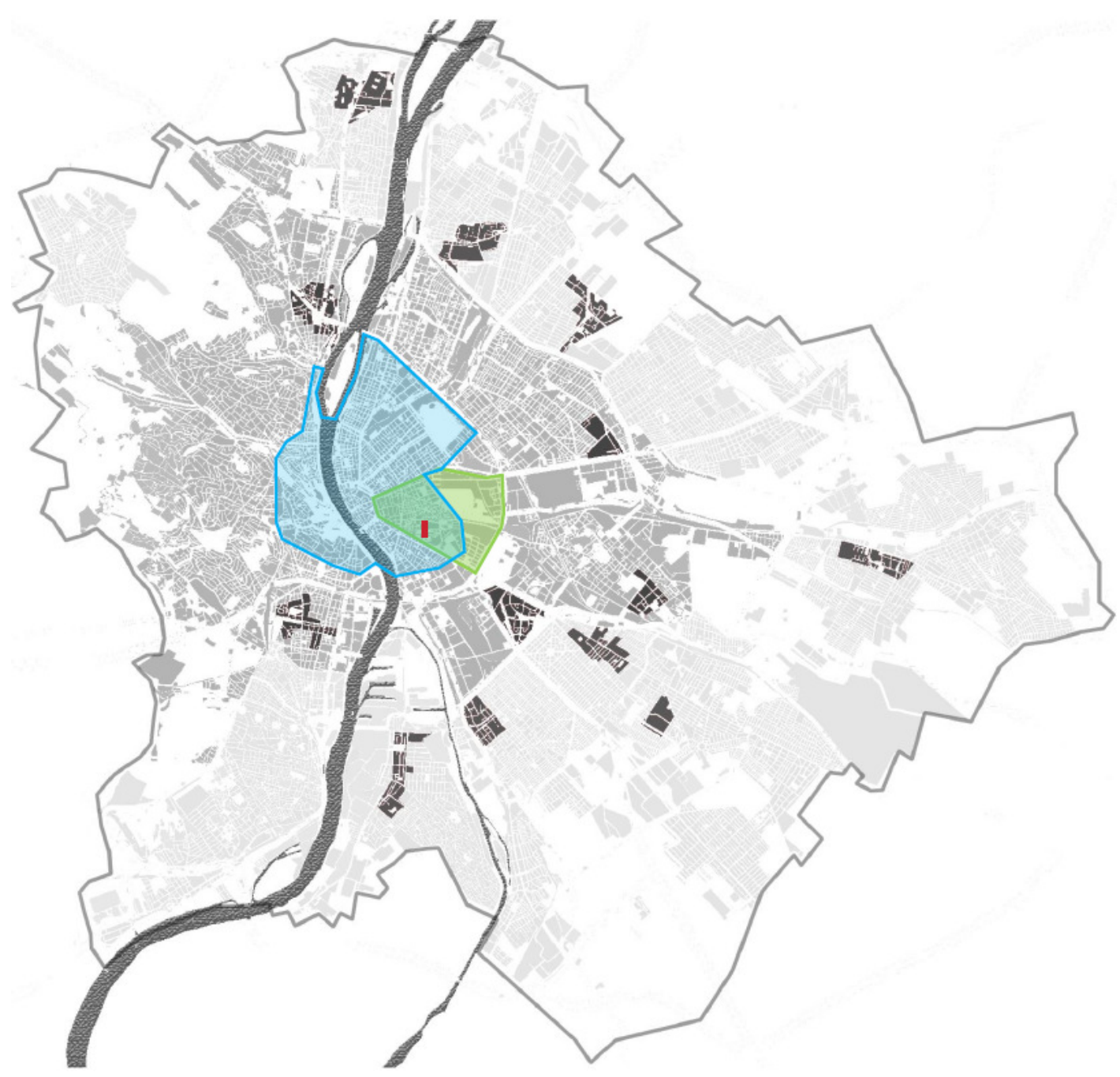

Figure 1. Map of Greater Budapest indicating different developments in the historical periods. Legend: Budapest between 1873 and 1950 (dark grey); suburban zone until 1950 (light grey); historic inner zone (blue); large housing estates with more than 6,000 dwelling units (black); Józsefváros, Budapest's 8th district (green); Szigony Street, the case study area (red). 
Corvin-Szigony Project) is underway, developed by contemporary neoliberal urban development concepts.

The area of Szigony Street represents a location in which a diverse range of urban concepts and experiences have been realized. It is not a typical part of the historic city center of Budapest where plot division, densification, and intensification characterized the changes. Here, the urbanization had always been dramatic, brand new, unknown, and large-scale intervention appeared based on contemporary objectives. Thus, Szigony Street is an ideal case to analyze and to understand theories and methods used by planners and check how their digital tools affect reality. Szigony Street itself is a short urban sequence that is squeezed between two main radial historic axes of Budapest, the Baross and the Üllői roads. Along this 750-meter-long street there are large-scale urban interventions with various building programs (housing estates, clinics, business district) and architectural styles (historic, modern, high-tech, etc.; see Figure 2).

Three periods can be distinguished in the planning and development of the Szigony Street area:

1. Traditional planning: The period from the mid-18th century to the Second World War, when the primary road network and building structure of the area were established and the essential components of the urban fabric were formed. The period was characterized by investor-led planning where planning and development were in alignment. Between 1870 and the First World War, the Council of Public Works played a decisive role in the development of the area alongside investors;

2. Modern planning: The second period coincided with the communist period. Between 1949 and 1990 , with the rise of modern architectural ideology in Central and Eastern Europe, the construction of high-rise housing estates began. Political ideology was also present in the construction of these large urban housing estates, so this period can be called a period of ideology-led planning from both an urban planning and an urban policy perspective. During this period, the area became a highly disrupted territory;

3. Contemporary planning: The third period started in the 1990s after the change of regime with the return of the market economy and investor-led planning. In this period, ICT and digitalization gave a boost to urban development and the use of digital tools in planning opened new possibilities.

\subsection{Traditional Planning: Atypical Historic Urban Fabric}

The urbanization of the site begun in the 1730s with the construction of the first buildings. This eastern outskirt area of Pest City received the name József (Josephinum) after the son of Maria Theresa, the Habsburg sovereign of Hungary, in 1777. The first plan defined the main roads and large urban gardens. After the unification of

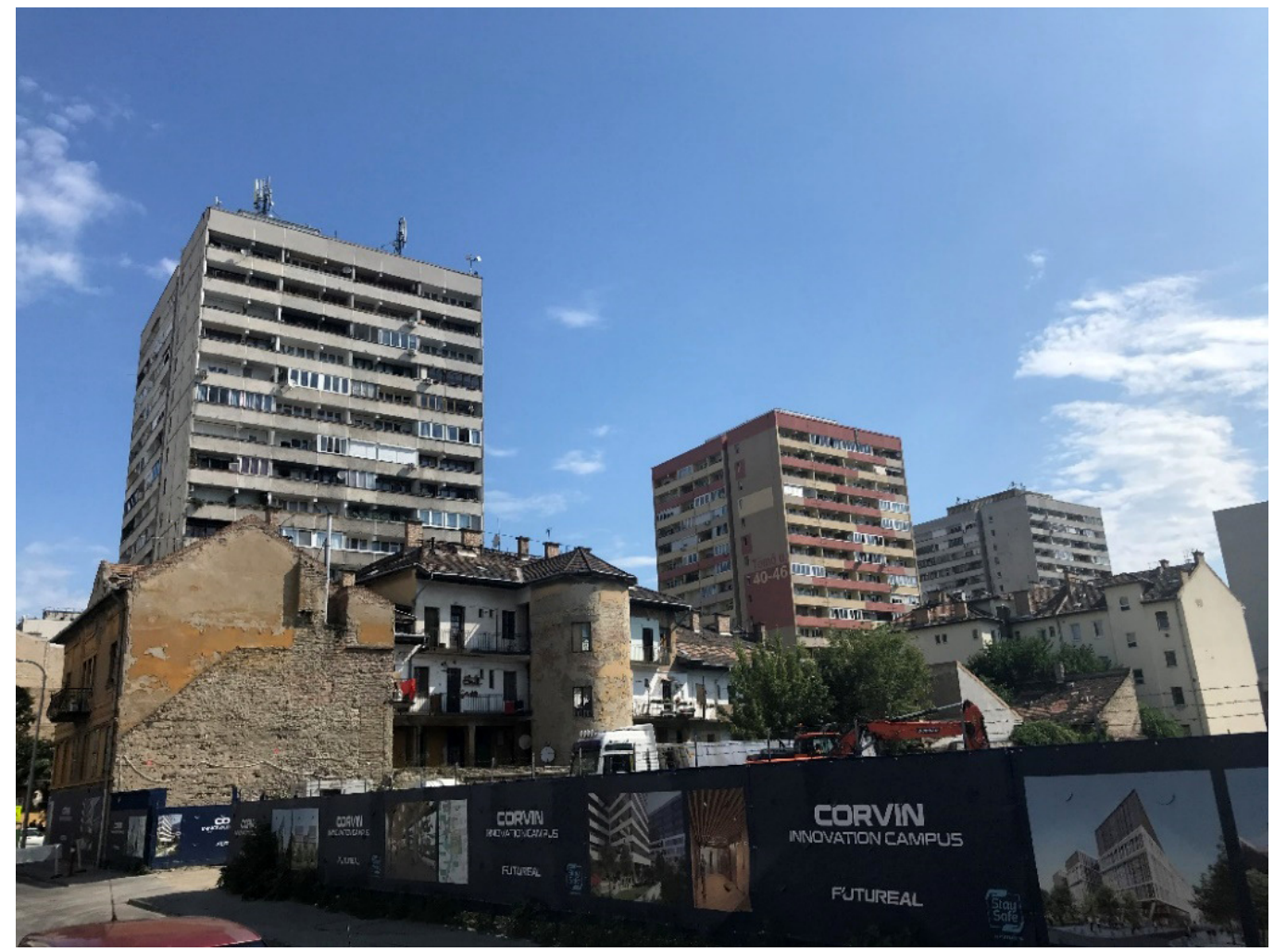

Figure 2. Budapest's Szigony Street. 
Pest, Buda, and Óbuda in 1873, Józsefváros became the 8th district of the Hungarian capital. Besides the typical development pattern of single, two, or three story-high simple courtyard residential buildings with small workshops, the former urban gardens of the area gave opportunity for large scale interventions as well. After completing its first medical faculty campus in inner-Józsefváros, the Royal Hungarian University of Science, in Budapest, developed a second one, the clinics on Szigony Street between 1898 and 1910. These clinics located in villas within a fenced green garden form the southern gate of the area. The catholic church owned another garden and a housing estate for the middle classes was built there between 1910 and 1912 (Papházak). This six-story high building complex forms a special historic urban island on the street.

\subsection{Modern Planning: Clearance and Replacement in Budapest's Inner City}

Following the urbanization of the interwar period, the consequences of Second World War, and the 1956 revolution, Middle-Józsefváros had one of the most neglected physical and social contexts in Budapest. During the state socialist period (1949-1989), mass-housing policy based on the Soviet model was initiated using large prefabricated concrete panels, and today, one third of Budapest's housing stock is located in modern neighborhoods of this kind. The first 15-year housing plan (1960-1975) focused on the efficient urbanization of green field areas, but, at the same time, it also identified some historic urban fabrics for clearance and replace- ment by slabs and towers. Most of them were former city centers somewhere in the outskirts of Budapest (e.g., Óbuda, Újpest, Csepel), but Middle-Józsefváros, as a problematic area, became the only area in which such interventions took place within the historic urban core. Since 1962, several masterplans have been prepared with similar foundations: preservation of the historic buildings along the main roads (József, Üllői, Baross) and the large-scale historic building complex (Corvin, Clinics, Papházak), but total demolition of the inner parts, blocks, and buildings with more than 5,800 dwelling units. Although the urban form of the replacement concepts using towers and slabs were planned in different versions, Szigony Street and the perpendicular Práter Street were always the main axes of the composition. This project was developed as Budapest's pilot model to find efficient modern solutions to demolish and replace the historic urban fabric. Finally, they transformed a 12-ha large part of Józsefváros only, where six 16-story high residential towers were built in 1970 , and some 10-13-story high slabs with more than 2,000 dwelling units by 1975 . In the mass housing estate, Szigony Street changed dimension and from a narrow street became a 70-meter-long grey valley providing space for a possible new main road planned across the historic urban fabric (see Figures 3 and 5).

\subsection{Contemporary Planning: Real vs. Virtual City}

Budapest, after the change of political and economic regime, introduced a non-hierarchical, dualmunicipal structure in 1990 and Józsefváros became

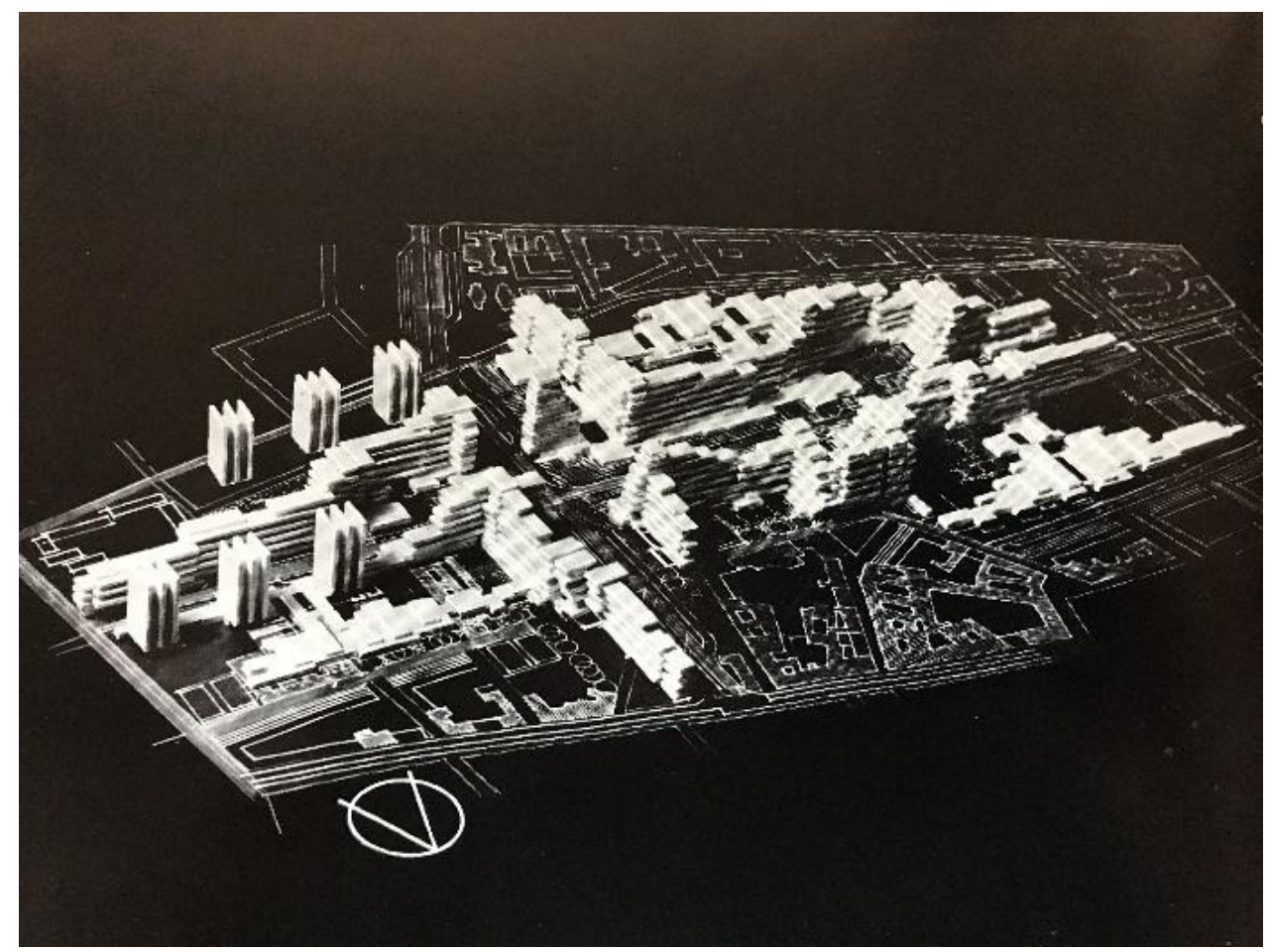

Figure 3. One of the proposals for the urban regeneration of Middle-Józsefváros in the 1960s. Source: Preisich (1973, p. 42). 
one autonomous administrative unit, the 8th of the 23 districts of the Hungarian capital. In 1997, the local government of Budapest and the 8th district's local government created the Rév8 Plc., a public company responsible for urban renewal. In 2000, the council of Józsefváros abandoned its former rehabilitation plan and decided to identify urban quarters based on physical and social data and introduce a quarter-based development and management approach. In 2005, the municipality approved the new spatial division and each of the eleven quarters became a local unit with different problems and potential. The quarters of Józsefváros started to develop differently in the 21st century (Alföldi et al., 2019). One of the 11 quarters, the Corvin Quarter, was prepared for total privatization giving the opportunity for a 22-ha large contemporary private development within Budapest's historic urban core (Kiss, 2019). At first, the name of the area was Corvin-Szigony, reflecting the western and eastern limits of the land; later it became the more international and real estate-friendly Corvin Promenade. The development started in 2005 and by 2018 reached Szigony Street, where it continues today with the Innovation Campus. This whole project is promoted as the largest Central European urban renewal within a historic city center. However, the concept, just like the earlier modern one, is based on tabula rasa, displacement of the residents, scale, and functional transformation (see Figure 4).

Szigony Street is partly situated in the Losonci Quarter and creates the borderline between the Losonci and the Corvin Quarters. These are the two quarters where the municipality does not use context-sensitive rehabilitation (Perczel, 1992) but has been managing a traditional top-down planning process since 2000 . To facilitate the re-evaluation of the Corvin investment area, the Rév8 Plc initiated some other private projects in the neighborhood. As a result, the Pázmány Péter Catholic University built one of its new buildings in the middle of the planned modern urban axis (Szigony Street) in 2008, and an apartment building was constructed behind the Papházak. In addition, here the modern high-rise housing estate of Szigony Street serves as a reference for contemporary urban development: total demolition of the past and replacement by dense, 30-meter high, urban-block sized residential or office buildings. Although this article focuses on the physical impacts of the urban renewal on the built environment, it is evident that this process has resulted in subsequent changes in the district's socio-spatial context (Czirfusz et al., 2015; Horváth, 2019).

\section{Space and Data: Digital Tools in Contemporary Planning and Design of the "Virtual" City}

The use of ICT and digitalization has opened new perspectives for urban planning and development worldwide. In the following section, we review the contemporary planning shaping the physical and social context of the Szigony Street area based on fieldwork and surveys undertaken with planning and design professionals in 2021.

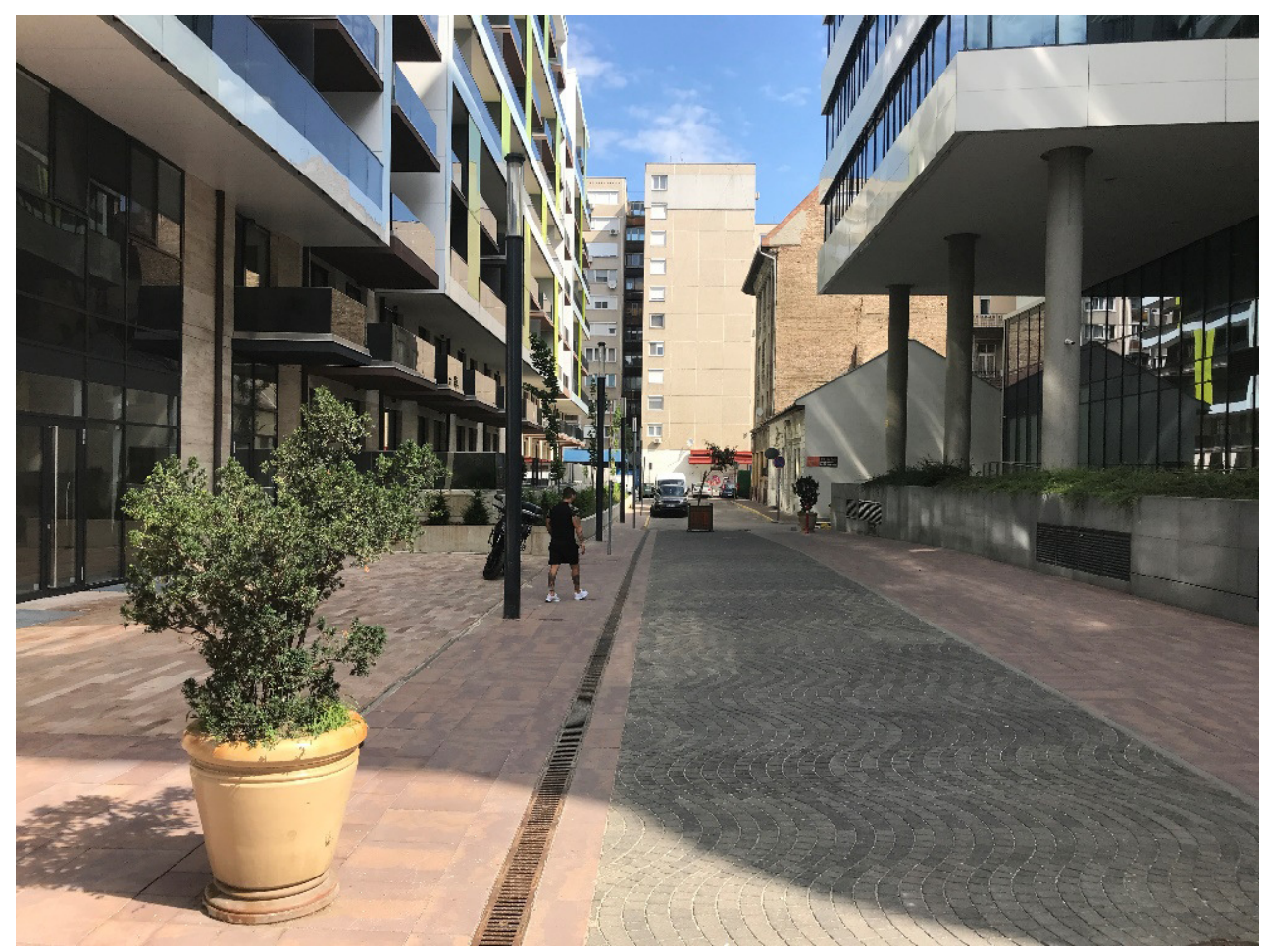

Figure 4. Urban diversity of the Szigony area: New residential buildings, prefabricated modern slabs, and historic tenements in the background. 


\subsection{Spatial Units}

Based on historic and contemporary development, the area can be divided into different morphological units, but they do not reflect any special characteristics based on ICT. It is easy to recognize them by their spatial segregation that exists not only in the urban form, but also in the social context of the urban blocks. In recent years, the density and the intensity of the areas increased and most of the public spaces - the undermanaged Szigony Street and the perpendicular overmanaged (Carmona, 2010) Corvin Promenade-created a place for urban diversity: Digital nomads, youngsters, and students use the same public areas as residents of the prefab slab buildings and towers or neglected historic tenement buildings (Czirfusz et al., 2015; see Figure 5).

\subsection{Planning and Design Units}

Following the historic inner city development where different private owners developed similar urban plots, the effective transformation started in the 1960s. Typical tenement houses were demolished to modernize the area, to change not only the physical but also the social context. This process was interrupted and, after decades of neglect, contemporary large-scale development started in the 21st century (see Figure 6). The first intervention was undertaken by the new Faculty of Pázmány Catholic University specialized in digital technology and robotics, but its building, like an enclosed fortress, occupied a part of the parking area of the housing estate in Szigony Street. Four-story high, stand alone, independent buildings organized around inner courtyards in the middle of the panel urban jungle in 2008 (see Figure 7). Then, after the global economic crisis, the Corvin Promenade was constructed in the Szigony Street area and large-scale office buildings provided a new facade to its central part in the last few years. These 9/10-story high, dense, controlled private developments for white-collar workers communicate intensively with the new Promenade, but on the narrow Szigony Street they have elevated levels and transparent glass walls without any public entrances. The Corvin Promenade Project is the only one of its kind and dimension in Budapest's inner city and it has changed the image and socio-economic status of the area completely.

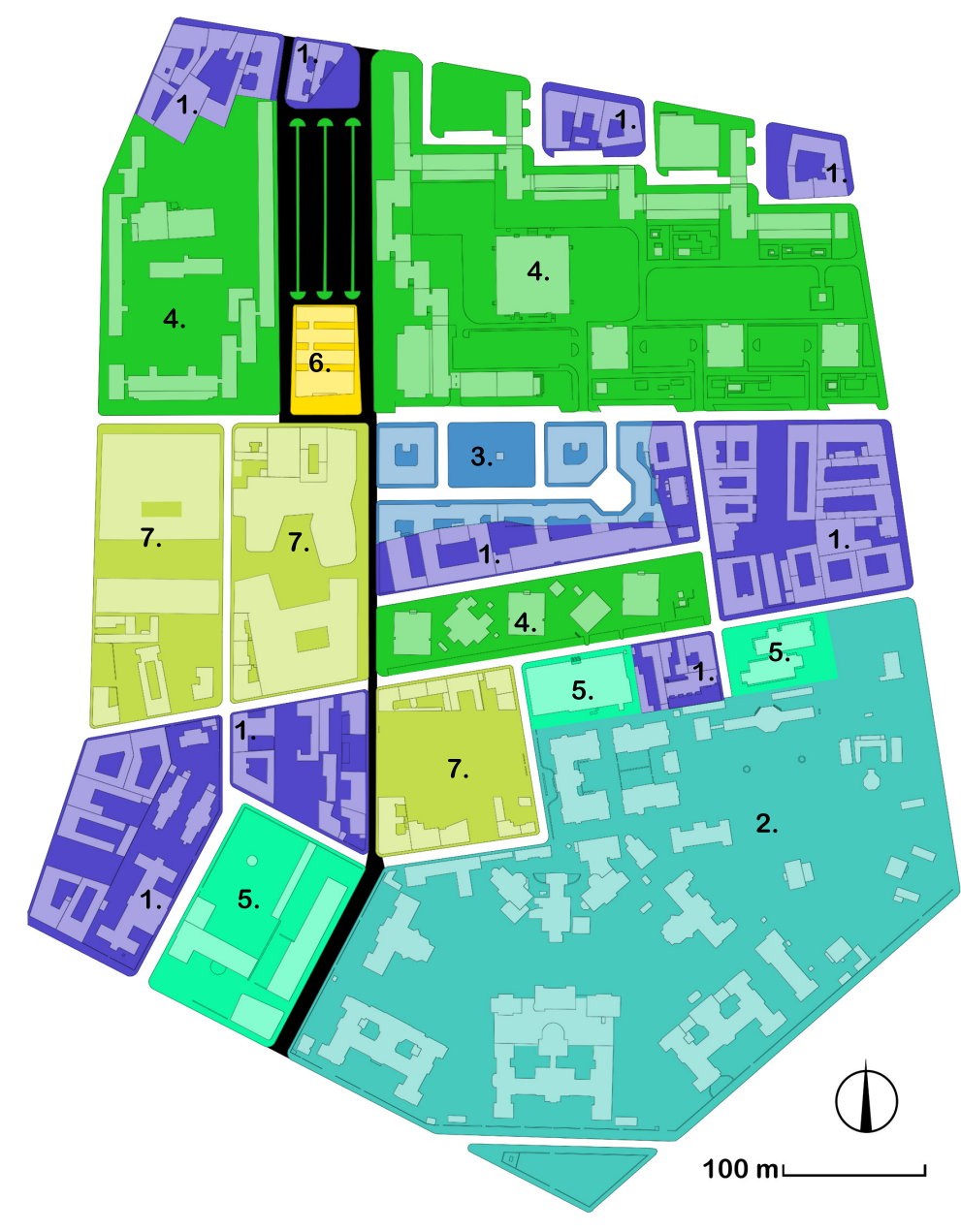

Figure 5. Contemporary urban fabric composed of different morphological units reflects disrupted developments. Legend: Corvin Street (black), (1) historic tenement buildings, (2) Clinics, (3) historic housing estate, (4) modern mass housing, (5) modern public buildings, (6) university building, and (7) Corvin Promenade. 


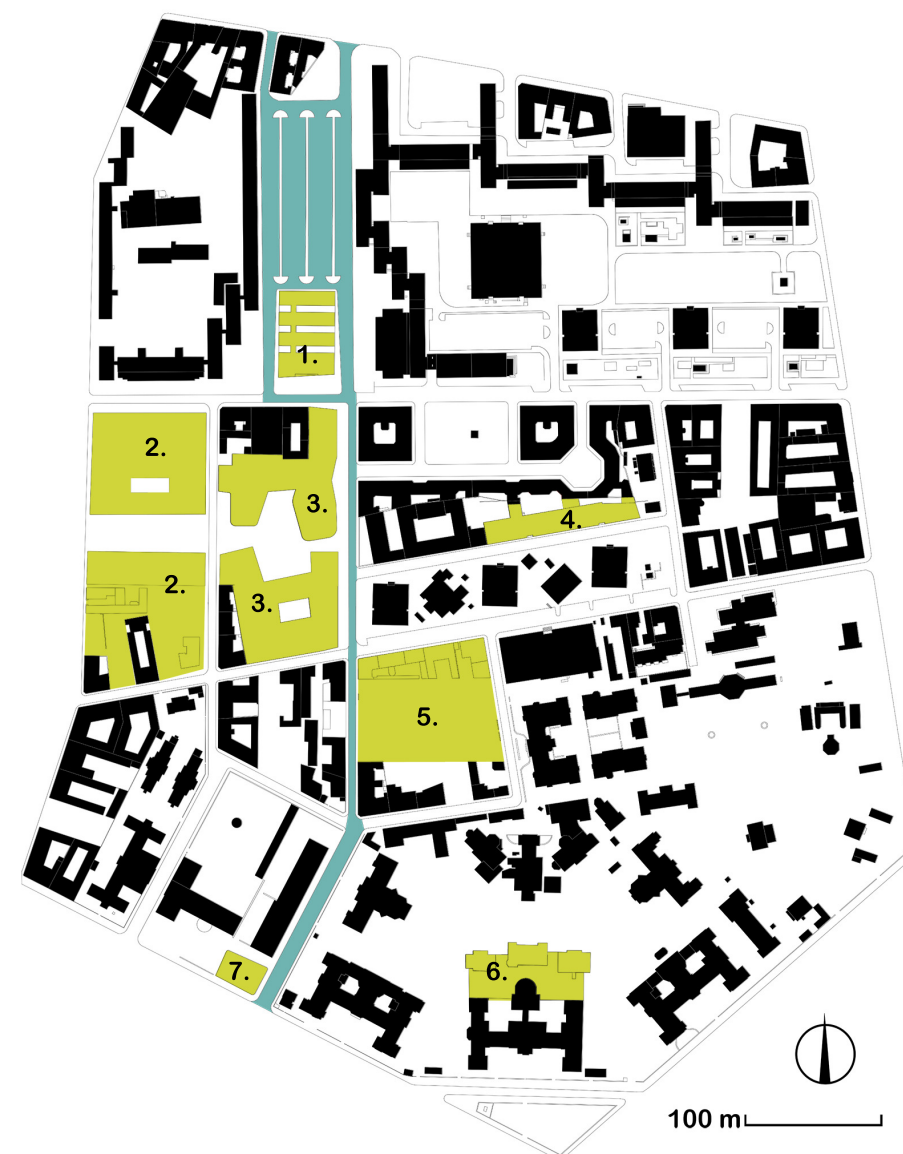

Figure 6. Contemporary large-scale development and design units. Legend: Corvin Street (blue), (1) Pázmány University building, (2) housing complex with more than 1,000 dwelling units, (3) Corvin Offices, (4) residential building, (5) Innovation Campus, (6) Clinics, and (7) Clinics Metro Station.

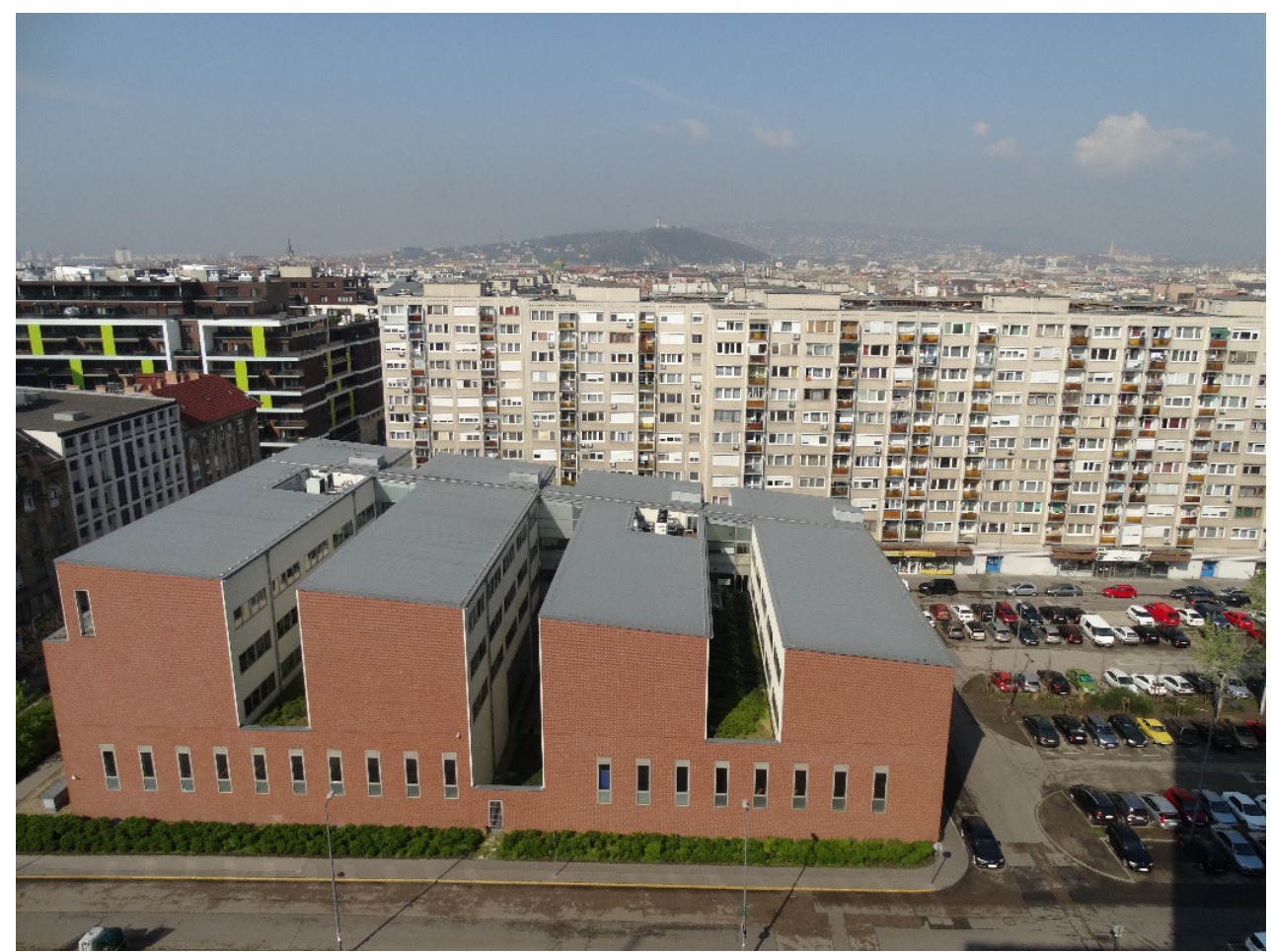

Figure 7. Szigony Street view from a panel building: The contemporary brick university building occupies a part of the planned urban highway between modern slab buildings without any communication with its surroundings. 
Densification, intensification, gentrification, and youngification characterize the Szigony Street area. New services and users appeared along the street and, in addition the southern gate of the area, the Clinics Metro Station will also be renewed soon. Investors continue to search for land to develop, for example the Innovation Campus will occupy a piece of land that belonged to former historic tenement buildings. It will be the first large scale building in the area, which will be connected to the street by a publicly used square and facilities on the ground floor. This design proposal demonstrates a metamorphosis of Szigony Street's image in the next 15 years.

\subsection{Digital Tools Used by Planning and Design Professionals}

In 2021 we carried out seven in-depth-interviews with planners and architects who were involved in the transformation of the Szigony Street area between 2002 and 2021. The questions were organized around different topics related to the planning and design process: methods and tools used during the data collection, methods and tools used during the realization and communication of the project, personal relationship to the site, and opinion about the current status of Szigony Street. It is important to recognize that most of them used traditional data collection methods based on fieldwork, so photo documentation, mapping, and offline meetings were still the basic tools for data collection. All interviewees used historic and statistical data, checked previous planning and design documents, and followed official EU and national regulations. CAD and GIS programs gave the professional background; however, digital tools providing participatory methods (Benkő et al., 2018), social media, or innovative visualization techniques to communicate the future were not introduced. In 2002, the original development concept was value-driven, focusing on economic and social potential and on this basis, the Corvin and Losonci Quarters of the 8th district became an inner city urban laboratory. There, the physical context reflects the changing policy, market, and interests. To explain the dimension and method of this radical contemporary intervention, reference was made to the modern urbanism of the mass housing neighborhood: clearing of the remaining historic area, replacement by large-scale projects, using traditional top-down planning and design resulting in densification and intensification. Projects were created using digital tools; however, ICT and digitalization had no direct impacts on the urban fabric.

\subsection{Open-Source Urban Data}

Data collection has always been and is still fundamental for every context-sensitive urban research, planning, and design process. Besides the official and sometimes highly prized data available in a native language, validated open-source and community-produced data are available remotely. Surveys show that in the case of Szigony Street, professionals did not use them neither for analysis nor for facilitating data-driven participation (Tenney \& Sieber, 2016). If planners are interested in users' opinion, social interfaces and applications could be useful for gaining information and creating surveys. In the Szigony Street area, several public and small private virtual social-media groups exist, but, according to local sources, they are still not well-organized.

The historic research was accompanied by several open-access databases. In Hungary, Fortepan (2010), a Hungarian-developed community-based copyright-free platform gives the opportunity to share archive photos of citizens and institutions. In 2021, almost 150,000 images are available, and several hundreds were taken in the Szigony Street area (see Figure 8).

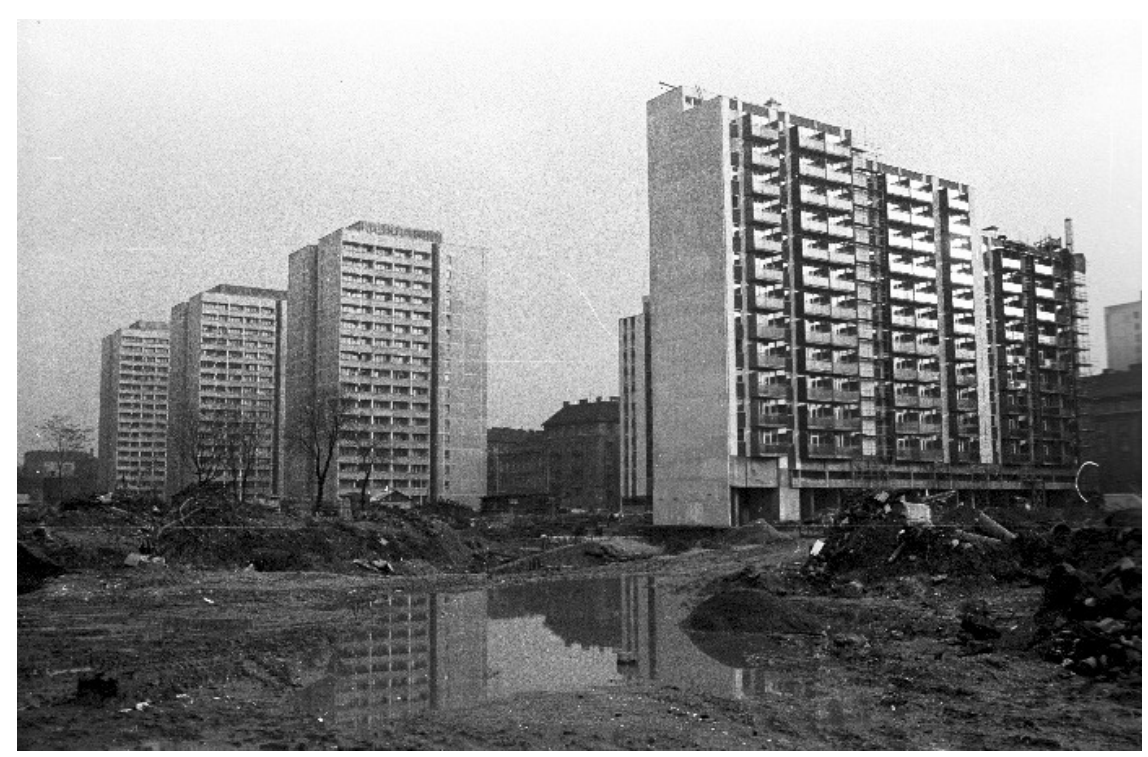

Figure 8. Modern mass housing estate on Szigony Street. Source: Fortepan (2010). 
In Hungary, the digitalization of the different public collections started in 2006. For example, Mapire (the historical map portal) is a geo-referenced interface presenting historical maps by GIS technology. The collection is based on the military surveys of the Habsburg Empire, country- and city-level, and thematic maps. Concerning any site in Budapest, urban changes can be easily traced from the middle of the 18th century to the middle of the 20 th century. However, more and more collection of written resources is also attainable on the web. Hungaricana (Hungarian cultural heritage portal), the most relevant local portal with documents of various public collections (libraries, archives, museums, state institutions, etc.) shows 2,181 documents in which Szigony Street is mentioned. In 2021, global, national, and local digital data exist; sometimes they are open-access (see Figure 9) and are geo-referenced, but for most of them a fee is required, and the spatial composition and distribution of statistical data are not relevant enough for the space of a planning or design project (Németh, 2020).

\section{Discussion and Conclusions}

Traditional planning is related to power and the urban fabric is shaped by political will and economic interest (Brenner, 2011; Fuller \& West, 2017). However, contemporary ICT and digitalization of the city seem to play several roles, and, among them, democratization of the planning process and governance are important ones (Hennen et al., 2020). Based on the analysis of the planning history of Szigony Street area in Budapest's inner city, three different phases are differentiated. The first is the traditional world with a planning framework given by the city (urban network, public facilities, regulation, etc.), where local private developers and investors construct the city plot by plot. The second is the modern urban regeneration in which demolition, modernization, scale transformation, and efficiency are basic concepts. In addition, this process in socialist cities was facilitated by the nationalization of land and buildings, central planning, and common soviet norms (Tosics, 2013). The planning methods and tools remained traditional but reflected the theory of modern urbanism about the future city. In the third phase, at the end of the 20th century, the world entered the digital age. However, for Budapest, and for other Central and Eastern European cities, it was the beginning of post-socialist capitalism, with mass privatization, globalization, economic value-driven development, and digitalization (Sýkora \& Bouzarovski, 2012). Traditional top-down planning and design methods continue to play a dominant role in urban development, with the role of ICT and digitalization mainly limited to database management and attractive visualization related to real estate industry requirements. In the case study area, the development of the modern mass housing neighborhood is characterized by demolition and replacement, top-down planning without participation and scale transformation continues with the help of digital methods and tools. As a result, real and virtual cities coexist. The hard, physical, and soft social components of the contemporary city develop in a different manner.

The case study area of Szigony Street in Budapest reflects these three planning phases perfectly. Some island-like historic tenement buildings co-exist with the inherited prefabricated modern housing estate and contemporary new large-scale developments. Diversity characterizes everything: urban form, functions, and users.

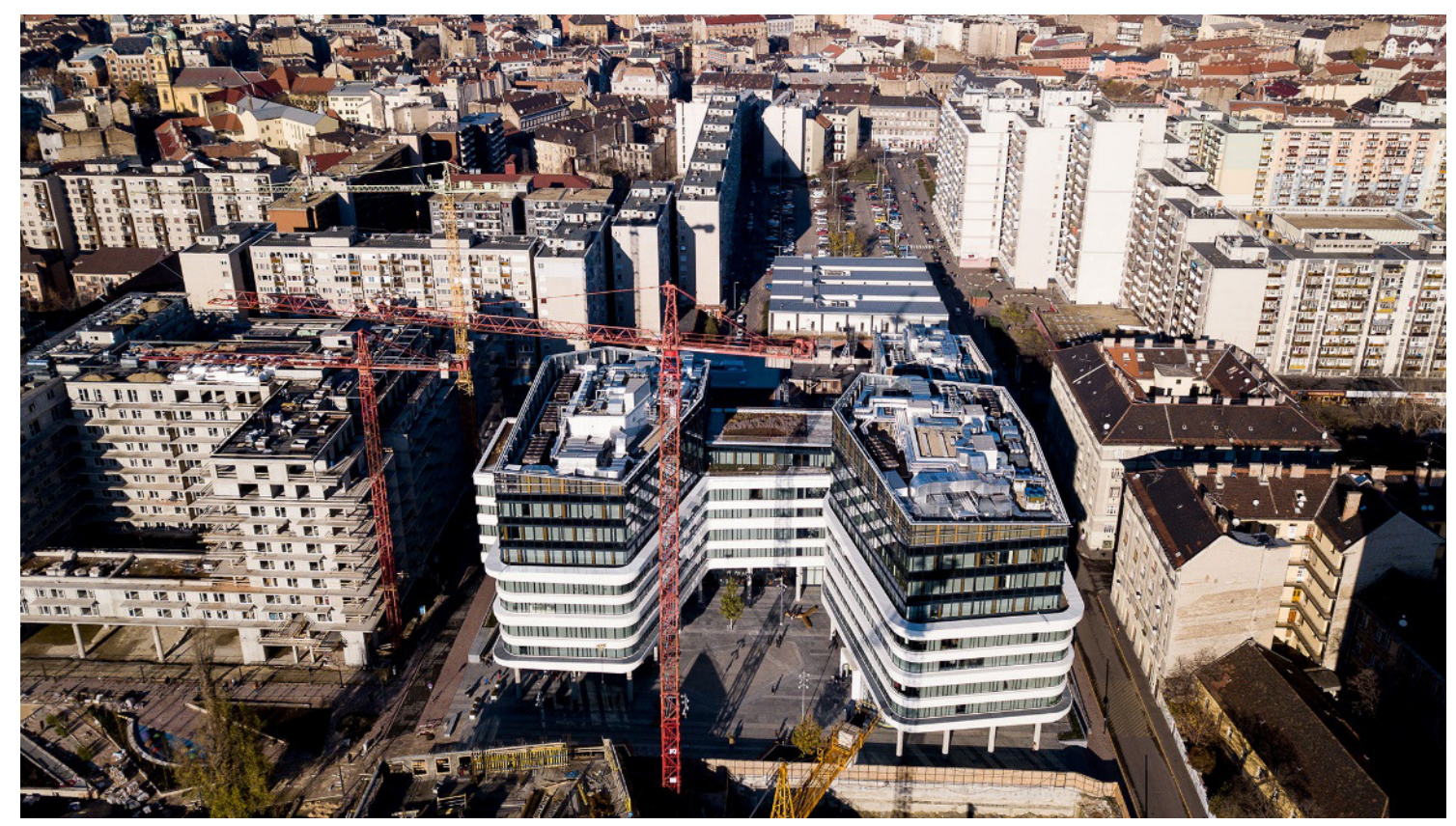

Figure 9. A public webcam took photos during the construction of a large-scale office building at the end of the Corvin Promenade and Szigony Street. 
At the same time, the real and virtual cities are increasingly overlapping and intertwined. The range and volume of data provided by sensors, digital networks, and statistical databases on the physical space are rapidly increasing. Locals know more and more about each other (by social network), about the history of the area (by openaccess digital resources) and about the actual and future transformations (by digital written and visual communication tools).

In line with the previous findings of Bibri and Krogstie (2017) and Lim et al. (2018), we stress that the importance of digitalization in urban planning is expected to increase in the near future. This is basically due to two processes. First, in urban planning, many of the urban renewal programs currently underway were launched in the 2000s (e.g., the Corvin project was developed in 1999-2004 and implementation started in 2005), when the degree of digitalization in Hungary and in urban planning was much less advanced. On the other hand, in recent years, we have witnessed an acceleration of digitalization. The degree and quality of digitalization of local society are constantly increasing thanks to socio-economic development, which has been reinforced by the impact of the Covid-19 pandemic of recent years (home office working significantly changed working methods and processes, new lifestyles, and attitudes; Sardar et al., 2021). Budapest's municipalities today introduce digital participatory methods about public space renewal projects, small interventions, and tactical urbanism. However, the actual and drastic transformations of major urban areas, construction of large-scale landmark buildings, change of the regulations, etc., take place using a conventional top-down approach supported by digital, intelligent, and smart methods and objectives.

The Szigony Street area changed significantly in the two last decades. Contemporary planners of the urban development projects, or designers of a large-scale building describe their concept as cooperative, generous, open-minded, innovative, but they think that the Szigony Street in 2021 is still dreary, contradictory, disproportionate, and incomplete. Can we really say that projects in the digital age are innovative? Did ICT and digitalization really change the traditional planning and design methods in practice? The reality is that although planned and well-promoted virtual cities already exist and new digital tools are shaping our daily life, the physical urban fabric is still planned and designed in a traditional way.

\section{Acknowledgments}

The research was funded by the COST Action 18137 MCMH-EU project and the National Research, Development, and Innovation Office of Hungary (Grant agreement No. K128717). This publication is based upon work from COST Action, European Middle Class Mass Housing (MCMH-EU) CA 18137 supported by COST (European Cooperation in Science and Technology). www.cost.eu

\section{Conflict of Interests}

The authors declare no conflict of interests.

\section{References}

Alföldi, G., Benkő, M., \& Sonkoly, G. (2019). Managing urban heterogeneity: A Budapest case study of historical urban landscape. In A. P. Roders \& F. Bandarin (Eds.), Reshaping urban conservation, creativity, heritage, and the city (Vol. 2, pp. 149-166). Springer.

Anttiroiko, A. (2021). Digital urban planning platforms: The interplay of digital and local embeddedness in urban planning. International Journal of E-Planning Research, 10(3), 35-49.

Audirac, I. (2005). Information technology and urban form: Challenges to smart growth. International Regional Science Review, 28(2), 119-145.

Batty, M. (2013). Big data, smart cities, and city planning. Dialogues in Human Geography, 3(3), 274-279.

Batty, M., Axhausen, K. W., Giannotti, F., Pozdnoukhov, A., Bazzani, A., \& Wachowicz, M. (2012). Smart cities of the future. European Physical Journal Special Topics, 214(1), 481-518.

Benkő, M., Balla, R., \& Hory, G. (2018). Participatory place-making in the renewal of post-communist large prefabricated housing estates: Újpalota case study, Budapest. Journal of Place Management and Development, 11(3), 223-241.

Bibri, S. E., \& Krogstie, J. (2017). ICT of the new wave of computing for sustainable urban forms: Their big data and context-aware augmented typologies and design concepts. Sustainable Cities and Society, 32, 449-474.

Bifulco, F., Tregua, M., Amitrano, C. C., \& D’Auria, A. (2016). ICT and sustainability in smart cities management. International Journal of Public Sector Management, 29(2), 132-147.

Brenner, N. (2011). New state spaces: Urban governance and the rescaling of statehood. New York University Press.

Carmona, M. (2010). Contemporary public spaceCritique and classification, part one: Critique. Journal of Urban Design, 15(1), 123-148.

Carrillo, F. J., Yigitcanlar, T., García, B., \& Lönnqvist, A. (2014). Knowledge and the city: Concepts, applications, and trends of knowledge-based urban development. Routledge.

Champion, E. (Ed.). (2019). The phenomenology of real and virtual places. Routledge.

Czirfusz, M., Horváth, V., Jelinek, C., Pósfai, Z., \& Szabó, L. (2015). Gentrification and rescaling urban governance in Budapest-Józsefváros. intersections. East European Journal of Society and Politics, 1(4), 55-77.

Douay, N. (2018). Urban planning in the digital age: From smart city to open government? Wiley.

Dufva, T., \& Dufva, M. (2019). Grasping the future of the digital society. Futures, 107, 17-28. 
Egedy, T., Kovács, Z., \& Kondor, A. C. (2017). Metropolitan region building and territorial development in Budapest: The role of national policies. International Planning Studies, 22(1), 14-29.

Firmino, R. J., Aurigi, A., \& Camargo, A. R. (2006). Urban and technological developments: Why is it so hard to integrate ICTs into the planning agenda? In M. Schrenk (Ed.), Proceedings of CORP 2006 \& geomultimedia 06 (pp. 143-152). Competence Center for Urban and Regional Development.

Fortepan. (2010). Home. https://fortepan.hu/en

Fuller, C., \& West, K. (2017). The possibilities and limits of political contestation in times of 'urban austerity.' Urban Studies, 54(9), 2087-2106.

Graham, S., \& Marvin, S. (1999). Planning cybercities: Integrating telecommunications into urban planning. Town Planning Review, 70(1), 89-114.

Hancke, G. P., de Carvalho e Silva, B., \& Hancke, G. P., Jr. (2013). The role of advanced sensing in smart cities. Sensors, 13(1), 393-425.

Hennen, L., van Keulen, I., Korthagen, I., Aichholzer, G., Lindner, R., \& Øjvind, N. R. (2020). European e-democracy in practice. Studies in digital politics and governance. Springer.

Hollands, R. (2008). Will the real smart city please stand up? Creative, progressive or just entrepreneurial? City, 12, 303-320.

Horváth, D. (2019). A városrehabilitáció társadalmi sokszínűségre gyakorolt hatásainak térbeli-társadalmi vizsgálata Józsefvárosban [The socio-spatial analyses of impacts of urban renewal on social diversity within Józsefváros]. Területi Statisztika, 59(6), 606-643.

Ishida, T., \& Isbister, K. (2000). Digital cities-Technologies, experiences, and future perspectives. Springer.

Katz, L. F., \& Krueger, A. B. (2016). The rise and nature of alternative work arrangements in the United States 1995-2015 (Working Paper No. 22667). National Bureau of Economic Research.

Kiss, D. (2019). Modelling post-socialist urbanization. The case of Budapest. Birkhäuser.

Kitchin, R. (2014). The real-time city? Big data and smart urbanism. GeoJournal, 79(1), 1-14.

Komninos, N. (2002). Intelligent cities: Innovation, knowledge systems, and digital spaces. Routledge.

Lim, C., Kim, K. J., \& Maglio, P. P. (2018). Smart cities with big data: Reference models, challenges, and considerations. Cities, 82, 86-99.

Losonczy, A. K., Balla, R., Antypenko, H., \& Benkő, M. (2020). Re-shaping Budapest: Large housing estates and their (un)planned centers. Architektúra \& Urbanizmus, 54(1/2), 44-55.

Malone, T. W. (2018). How human-computer "superminds" are redefining the future of work. MIT Sloan Management Review, 59(4), 34-41.

McFarlane, C. (2011). The city as assemblage: Dwelling and urban space. Environment and Planning D: Society and Space, 29, 649-671.

McQuire, S. (2021). Urban digital infrastructure, smart cityism, and communication: Research challenges for urban e-planning. International Journal of E-Planning Research, 10(3), 1-18.

Molnár, V. (2013). Building the state: Architecture, politics, and state formation in postwar Central Europe. Routledge.

Nam, T., \& Pardo, T. A. (2011). Conceptualizing smart city with dimensions of technology, people, and institutions. In S. A. Chun, L. Luna-Reyes, \& V. Atluri (Eds.), Digital government innovation in challenging times (pp. 282-291). ACM.

Nambisan, S., Wright, M., \& Feldman, M. (2019). The digital transformation of innovation and entrepreneurship: Progress, challenges, and key themes. Research Policy, 48(8), 1-9.

Németh, Z. (2020). A hivatalos statisztika válsága az adatforradalomban [The crisis of official statistics in the data revolution]. Replika, 2020(117/118), 179-210.

Pancholi, S., Yigitcanlar, T., \& Guaralda, M. (2015). Place making facilitators of knowledge and innovation spaces: Insights from European best practices. International Journal of Knowledge-Based Development, 6(3), 215-240.

Perczel, A. (1992). A Közép-Józsefváros északi területére készülő Részletes Rendezési Terv programja [Detailed plan and program of the northern part of CentralJosephstadt in Budapest]. Tér és Társadalom, 6(3/4), 89-162.

Perry, B. (2008). Academic knowledge and urban development. In T. Yigitcanlar, K. Velibeyoglu, \& S. Baum (Eds.), Knowledge-based urban development (pp. 21-41). Routledge.

Portugali, J., Meyer, H., Stolk, E., \& Tan, E. (2012). Complexity theories of cities have come of age: An overview with implications to urban planning and design. Springer.

Preisich, G. (Ed.). (1973). Budapest jövője [The future of Budapest]. Műszaki Könyvkiadó.

Sardar, T., Jianqiu, Z., Bilal, M., \& Syed, N. (2021). Impact of ICT on entrepreneurial self-efficacy in emerging economy: Sustaining lock-down during COVID-19 pandemic. Human Systems Management, 40(2), 299-314.

Sassen, S. (2001). Impacts of information technologies on urban economics and politics. International Journal of Urban and Regional Research, 25(2), 411-418.

Schaffers, H., Komninos, N., Pallot, M., Trousse, B., Nilsson, M., \& Oliveira, A. (2011). Smart cities and the future internet: Towards cooperation frameworks for open innovation. In J. Domingue, A. Galis, A. Gavras, T. Zahariadis, D. Lambert, F. Cleary, P. Daras, S. Krco, H. Müller, M.-S. Li, H. Schaffers, V. Lotz, F. Alvarez, B. Stiller, S. Karnouskos, S. Avessta, \& M. Nilsson (Eds.), The future Internet-Future Internet Assembly 2011: Achievements and technological promises (pp. 431-446). Springer.

Sýkora, L., \& Bouzarovski, S. (2012). Multiple transformations: Conceptualising the post-communist urban 
transition. Urban Studies, 49, 43-60.

Tenney, M., \& Sieber, R. (2016). Data-driven participation: Algorithms, cities, citizens, and corporate control. Urban Planning, 1(2), 101-113.

Tosics, I. (2013). From socialism to capitalism: The social outcomes of the restructuring of cities. In N. Carmon \& S. Fainstein (Eds.), Policy, planning, and people. Promoting justice in urban development (pp. 75-100). University of Pennsylvania Press.

Townsend, A. (2013). Smart cities: Big data, civic hackers, and the quest for a new utopia. W.W. Norton \& Company.

Tranos, E. (2013). The geography of the internet: Cities, regions and internet infrastructure in Europe. Edward Elgar Publishing.

Tranos, E., \& Nijkamp, P. (2013). The death of distance revisited: Cyber-place, physical and relational proximities. Journal of Regional Science, 53(5), 855-873.
Virtual. (n.d.). In Cambridge dictionary. https:// dictionary.cambridge.org/dictionary/english/virtual

Wareham, J., Fox, P. B., \& Cano Giner, J. L. (2014). Technology ecosystem governance. Organization Science, 25(4), 1195-1215.

Washburn, D., Sindhu, U., Balaouras, S., Dines, R. A., Hayes, N., \& Nelson, L. E. (2009). Helping CIOs understand 'smart city' initiatives. Growth, 17(2), 1-17.

Yeh, H. (2017). The effects of successful ICT-based smart city services: From citizens' perspectives. Government Information Quarterly, 34(3), 556-565.

Yigitcanlar, T. (2011). Redefining knowledge-based urban development. International Journal of Knowledge Based Development, 2(4), 340-356.

Zysman, J., \& Kenney, M. (2018). The next phase in the digital revolution: Abundant computing, platforms, growth, and employment. Communications of the ACM, 61(2), 54-63.

\section{About the Authors}

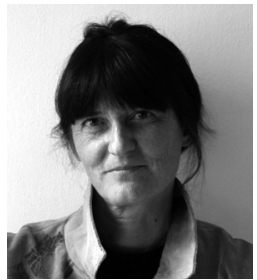

Melinda Benkö (PhD and habilitation in architecture) is an associate professor at the Budapest University of Technology and Economics Department of Urban Planning and Design. She earned a Campus France, MTA Bolyai, and Fulbright Grants, and is currently the chair of the "Facing Post-Socialist Urban Heritage" doctoral conference series and member of the Committee on Architecture at the Hungarian Academy of Sciences. Benkő's research, academic, and professional activities focus on contemporary urban design theory and practice related to urban form and space usage.

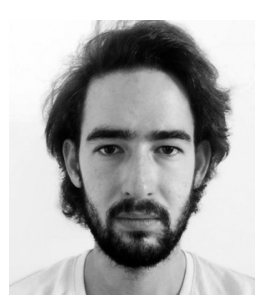

Bence Bene is a PhD student of the Department of Urban Planning and Design at Budapest University of Technology and Economics. He has published on the mobility of homeless people in Budapest and informal urbanism in Tirana. Bence is working as an architect in an NGO called "From Streets to Home Association," helping to solve the issues of homelessness and other types of housing crises in Budapest. Recently, he has researched the spontaneous urban patches of Hungarian post-socialist mass housing estates.

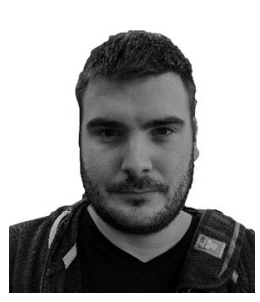

Ádám Pirity graduated with an MSc degree from the Faculty of Architecture of the Budapest University of Technology and Economics. In the fall of 2020, he was admitted to the university's Pál Csonka Doctoral School. The main topic of his doctoral research is to explore the history and operation of a design company operating in the period of state socialism in northern Hungary. Collecting and organizing various data has become an important part of his research activities.

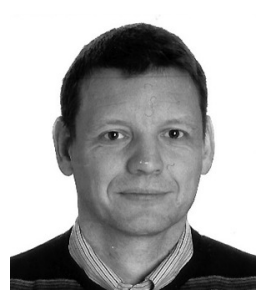

Árpád Szabó (DLA) is an architect and urban designer. He obtained his diploma at the Budapest University of Technology and Economics' Faculty of Architecture in 1999 and finished his DLA studies at the Doctoral School of Architecture in 2007. Since 2003, he has been teaching at the Department of Urban Planning and Design and since 2019 he has been the head of the department. He works mainly on urban design projects at his own studio (Czirjak Szabo).

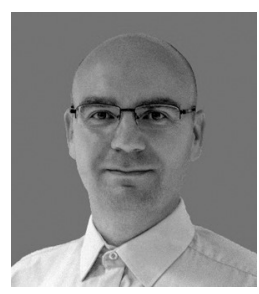

Tamás Egedy (PhD) is an urban geographer. He is senior research fellow at the Geographical Institute of the Research Centre for Astronomy and Earth Sciences and associate professor at the Budapest Business School. His research activities are in the field of urban regeneration, housing estates, and creative economy in Hungary. He is editor of the leading Hungarian geography journals Hungarian Geographical Bulletin and Geographical Review. 